\title{
GCU
}

Glasgow Caledonian

University

University for the Common Good

\section{High performance in healthcare priority setting and resource allocation: a literature- and case study-based framework in the Canadian context}

Smith, Neale; Mitton, Craig ; Hall, William; Bryan, Stirling ; Donaldson, Cam; Peacock, Stuart; Gibson, Jennifer L.; Urquhart, Bonnie

Published in:

Social Science and Medicine

DOI:

10.1016/j.socscimed.2016.06.027

Publication date:

2016

Document Version

Author accepted manuscript

Link to publication in ResearchOnline

Citation for published version (Harvard):

Smith, N, Mitton, C, Hall, W, Bryan, S, Donaldson, C, Peacock, S, Gibson, JL \& Urquhart, B 2016, 'High performance in healthcare priority setting and resource allocation: a literature- and case study-based framework in the Canadian context', Social Science and Medicine, vol. 162, pp. 185-192.

https://doi.org/10.1016/j.socscimed.2016.06.027

\section{General rights}

Copyright and moral rights for the publications made accessible in the public portal are retained by the authors and/or other copyright owners and it is a condition of accessing publications that users recognise and abide by the legal requirements associated with these rights.

Take down policy

If you believe that this document breaches copyright please view our takedown policy at https://edshare.gcu.ac.uk/id/eprint/5179 for details of how to contact us. 
High Performance in Healthcare Priority Setting and Resource Allocation: A Literature- and Case Study-based Framework in the Canadian Context 


\begin{abstract}
Priority setting and resource allocation, or PSRA, are key functions of executive teams in healthcare organizations. Yet decision-makers often base their choices on historical patterns of resource distribution or political pressures. Our aim was to provide leaders with guidance on how to improve PSRA practice, by creating organizational contexts which enable high performance. We carried out in-depth case studies of six Canadian healthcare organizations to obtain from healthcare leaders their understanding of the concept of high performance in PSRA and the factors which contribute to its achievement. Individual and group interviews were carried out $(\mathrm{n}=62)$ with senior managers, middle managers and Board members. Site observations and document review were used to assist researchers in interpreting the interview data. Qualitative data were analyzed iteratively with the literature on empirical examples of PSRA practice, in order to develop a framework of high performance in PSRA.

The framework consists of four domains - structures, processes, attitudes and behaviours, and outcomes - within which are 19 specific elements. The emergent themes derive from case studies in different kinds of health organizations (urban/rural, small/large) across Canada. The elements can serve as a checklist for 'high performance' in PSRA. This framework provides a means by which decision-makers in healthcare might assess their practice and identify key areas for improvement. The findings are likely generalizable, certainly within Canada but also across countries. This work constitutes, to our knowledge, the first attempt to present a full package of elements comprising high performance in health care PSRA.
\end{abstract}

\title{
KEYWORDS
}

Resource allocation; priority setting; healthcare management; high performance; Canada 


\section{INTRODUCTION/BACKGROUND}

Healthcare decision makers face two main impediments with respect to priority setting and resource allocation, or PSRA. (On how we define key terms in this paper, see Supplemental File One: Notes on terminology.) The first is a lack of skills in these endeavours (Lomas, Veenstra, Woods, 1997; Bate, Donaldson, and Murtagh, 2007) while the second pertains to the organization and culture of healthcare management, where processes, attitudes and incentives have been shaped by and implicitly continue to support PSRA based on historical patterns (Mitton and Donaldson, 2003b; Peacock et al., 2010).

To address the first challenge, research has focused on means to institute formal PSRA procedures within organizations (Mitton and Donaldson, 2004a). Much less attention has been paid to how different organizational contexts affect the quality of realized PSRA. We have limited knowledge of how barriers and facilitators to successful implementation (e.g., Mitton and Donaldson, 2004b; Gibson et al, 2005b; Sibbald et al, 2009) are arrayed as structures, processes and behaviours that would enable 'high performance' (see Supplemental File One for more on this concept). While there have been previous studies which proposed systems for evaluating resource allocation, there has not previously been a framework which organizes key elements around the concept of high performance. This paper addresses two research questions: 'How can 'high performance' with respect to health care priority setting be defined', and 'can a framework for achieving excellence in priority setting adequately capture relevant aspects of high performance'? We define high performance through the creation of such a framework, rooted in the experiences and wisdom of healthcare leaders in several Canadian organizations.

\section{METHODS/APPROACH}


Here, we provide an overview of how this research was conducted; a more detailed description of methods is provided in Supplemental File Two. We reached our conclusions about high performance in PSRA by integrating evidence from qualitative research in six Canadian healthcare organizations with the empirical literature. Case studies (Stake, 1995) provided us with detailed descriptions of situated PSRA processes, and their strengths and weaknesses as understood by healthcare leaders. First, we describe case and key informant selection and the interview process. Then, we indicate how qualitative analysis proceeded iteratively with our review of the empirical literature on PSRA.

We made deliberate effort to include different types of organization, such as individual hospitals and integrated health service delivery authorities; we also sought diversity in terms of budget size (large and small), as well as other factors. (See Table 1 for how these factors were ultimately balanced across cases.) In other words, cases were chosen in order to maximize learning (Stake, 1995). One case site in each of six regions across Canada (see Supplemental File One) was selected from among sites which we identified as potentially 'high performers' (See Supplemental File Two).

At each site, we sought to interview members of the senior management team (SMT), a sample of middle managers (those who report directly to a member of the SMT) from a range of program areas, and one or two governing Board members. Interviews used a semi-structured guide, including such topics as how respondents personally defined high performance in PSRA, their assessment of current strengths and weaknesses, and whether or not they agreed with the judgment of peers that their organization was a 'high performer'.

Most data collection occurred between February and June 2012; some interviews were conducted after that time due to participant availability or to address specific unanswered 
questions at select sites. Interviews were audiotaped and transcribed with consent; a total of 62 persons participated, with a range of 5-17 persons per site. Ethics approval was obtained by the Behavioural Research Ethics Board at the principal investigator's institution, as well as local REBs from individual case study sites when requested.

Data analysis began with four domains as a starting template (King, 2004). We postulated, in line with Donabedian's work on health care quality (1988), that PSRA outcomes depend upon institutional structures and organizational processes within which decision makers consider problems and make choices. We also deemed decision maker attitudes and behaviours a key determining factor. These four domains are depicted in Figure 1 (and See Supplemental File Two for more details). Beginning with these domains, we identified sub-themes (elements) inductively. These emerging qualitative themes - elements of high performance -- guided our investigation of the literature. That is, we assessed published studies of PSRA practice in other jurisdictions to confirm where case study themes were consistent with these larger findings, and to pinpoint areas where case studies and literature might diverge.

\section{RESULTS}

Synthesizing across our cases, along with the literature and our own experiences, we are able to describe what appear to be key elements within the four domains of high performance in relation to organization-wide PSRA. Table 2 presents each element both in terms of the case study analysis and its coherence with the literature. Supplemental File Three provides additional commentary, for instance noting where our findings fail to reflect or serve to extend existing literature, and where evidence for an element is limited in either our data or the literature. Each element is framed in a normative fashion, e.g., that healthcare organizations 'will' or 'should' do $\mathrm{X}$ in order to achieve high performance in PSRA. We included in the framework only those 
elements which we found in more than one case study through qualitative analysis, and which were corroborated by some previous mention in the larger PSRA literature we reviewed. Beyond this basic level we did not assign 'weights' to the frequency with which elements were described in informants' responses. Nuances or interesting interpretive elements could however be derived from description in a single case. This is consistent with qualitative research practice in which the presence or interpretive value of a theme does not depend upon straightforward numerical counts (Pope et al, 2000).

As Table 2 and Supplemental File Three suggest, most of the elements identified through qualitative analysis have also been identified as relevant to priority setting performance elsewhere in the literature. The outcome elements proved most difficult to construct. One notable divergence between our case studies and the literature is around the outcome of actual reallocation - this was not raised by informants, who appeared to consider that improving processes was their most important focus. Nonetheless we retained this, due to its prominence in other research. Neither the literature nor our case studies were able to shed much light upon ultimate outcomes - how to assess whether PSRA processes in fact contribute to the achievement of health organization goals and population and client health improvements. Our respondents shared the perception that a culture of improvement is linked to high performance and we included this domain, though the literature itself is inconclusive (Scott et al, 2003). In terms of fair process, the absence of an appeals mechanism - a central tenet of A4R (Daniels and Sabin, 2002) - did not seem overly of concern to our informants.

Reviewing Table 2, readers will see that case study sites overall judged themselves to be strong in terms of leadership and desire to be better priority setters and in resisting overt political pressures, but found their efforts to be weaker when it came to effective models of staff and 
public engagement, communications, disinvestment, and ensuring that processes were not overly time- and effort-demanding. Seemingly important elements, but for which we can yet offer relatively little specific guidance for practice, include the nature of leadership, the kinds of education and training needed, and the role of a designated PSRA coordinator. Finally, we would suggest that neither the literature or our own research here yet sheds much light on whether or not the factors conducive to high performance would also contribute to the sustainability of formal approaches to PSRA over time.

\section{DISCUSSION}

This study has proposed a comprehensive set of attributes to define high performance PSRA in health institutions. One strength of these findings is the combination of methods used to ground this descriptive framework, integrating lessons from an international literature with detailed qualitative interviews from decision makers across Canada. Our research sites spanned a range of settings with distinct challenges. While much past research has promoted particular techniques, or looked at factors which facilitate or hinder PSRA in individual situations, our efforts here distill characteristics across contexts which seem to matter regardless of organizational configurations or models of PSRA practice. This unifies treatment of structures, processes, behaviours and outcomes. Our results thus focused upon common themes. Finding substantive areas of divergence between types of site, for instance urban or rural, was not a primary aim of the study; nonetheless we can report that we found no apparent pattern in responses among the different types of site. (This is consistent with our earlier survey work (Smith et al 2013) where approaches to PSRA did not appear to differ between healthcare organizations of different sizes or geographies.) There have been some few past studies which propose systematic ways of assessing PSRA experience. Sibbald et al (2009) propose a 
framework of 10 dimensions, five related to process and five to outcomes. These authors suggested that their research was an "initial attempt to evaluate priority setting decisions in a specific context" and that "future research is required to determine the best combination of components" - building on this work, we have adapted many of their dimensions into our model of high performance. Kapiriri and Martin (2009) have offered an approach to priority setting evaluation specific to the context of developing countries. In the UK, a set of 11 competencies that would enable 'world class' commissioning were developed for Primary Care Trusts, or PCTs (McCafferty et al, 2012). Before these could be widely tested, NHS reforms abolished PCTs in favour of Clinical Commissioning Groups, for which a new set of nine resource allocation competencies was created (Russell et al., 2013). These competencies include areas such as communication, ethical judgement, evidence assessment and external communication. According to the authors, "evidence is emerging [that this framework] is being used as a starting point to help CCGs reflect on their future needs as resource allocators" (p. 123). These frameworks have considerable overlap with our own. Every organization faced with limited resources has to make choices about what to fund and what not to fund; we expect that while the elements underlying good practice for this choice-making may differ to some (limited) degree across jurisdictions, the elements of high performance we have identified through our work in Canada could serve at a minimum as a starting point for discussion in other settings as well.

The boundaries between the elements are clearly not watertight; depending on how it is framed, a particular attribute could for instance be seen as a structure, or as a behaviour exhibited within structures or processes. We were more concerned, in this first effort at articulating the idea of high performance in PSRA, with the inclusion of all significant elements than with their precise placement within our framework. Note that our framework includes all the factors we 
have identified as relevant to high performance, without attempting to establish a hierarchy or pattern of relations among them. This should be the subject of additional research. We can envision, for instance, that the absence of certain elements (such as lack of staff engagement due to a history of antagonistic interactions between physicians and administrators) might undermine the chances of others (such as a formalized PSRA process) being successfully put in place. This suggests that the framework might be used to assess organizational readiness in addition to post hoc evaluation of PSRA activities.

\section{Limitations.}

We acknowledge potential limitations. We used a traditional approach to literature review rather than explicit systematic review techniques. Such reviews can be criticized for being subjective (Rumrill and Fitzgerald, 2001). However our approach identified the most directly applicable evidence for testing our emerging set of elements. Some potentially relevant material, possibly unknown to the research team despite its many collective years of experience in the field, may have been missed. We also stuck closely to healthcare PSRA literature; more broadly engaging with other management literatures, some of which are suggested in Table 2, might bring additional insights and is worth pursuing in future study. For some topics we were not able to dive as deeply as we would have liked. For example, the literature has given considerable attention to public engagement in priority setting, and more recently, the issue of disinvestment is arising with increased frequency. While these are important topics, the structure of this paper does not allow for in depth cover of any given element within the overall framework. The aim of this paper is to present the framework in its entirety. Subsequent research can elaborate upon and refine our understanding of individual elements of high performance, as guided by the needs of healthcare decision makers. 
Finally, as in qualitative research generally, data collection and analysis in this study is fundamentally rooted in the collective experience of the research team. The definition of high performance in PSRA which we have arrived at, presented here in the framework of domains and elements, is thus also inextricably bound up with our experiences, knowledge and perspectives. The authors have experience with PSRA in several national contexts, though primarily in the developed world and in countries with publicly-funded universal health insurance models. Most of our work is at the meso-level, i.e., resource allocation by and within healthcare organizations, rather than at the political or bedside levels. While mainly health economists, our team is multidisciplinary with expertise in ethics and policy research as well. Other researchers and practitioners - with different formative experience and philosophical orientations -- should reflect upon our conclusions against the background of their own situated knowledge.

Our survey referral system and use of an Expert Panel to suggest organizations should have brought us to sites where there was much to learn. A different group of respondents might have suggested to us different organizations as a starting point. Nonetheless, the emergent themes are present in case studies from different kinds of health organizations (urban/rural, small/large) across Canada. Were the sites in which we conducted this work truly high performing organizations? The value of our data should not depend upon solely whether or not these organizations could objectively be considered to own that label, since our aim here is to build a grounded definition, not to measure a pre-existing construct. There is no reason to believe that these managers would be less likely than others in similar positions to understand what is required for high performance in PSRA. They do of course have years or decades of practical experience in this field. A different design, for instance, might have looked at 'low performing' organizations. We strongly suspect that managers here would point to the same elements as 
being of critical importance; that said, further work with additional organizations across a range of settings is surely needed to determine if the findings resonate with healthcare decision makers more broadly.

The practical applicability of this work is as a means for decision makers to introspect on their own organization or system and determine where they are lacking across the elements outlined here. We would theorize that improving practice in areas of perceived weakness would lead to a stronger, fairer process for PSRA and better use of limited resources. While this research drew upon experiences of several organizations to identify elements of high performance, we did not as part of the research provide explicit assessment of the processes in place at those sites. Rather, we synthesized their input in developing an evaluative tool which has been tested in other settings (Hall et al., 2016).

\section{CONCLUSION}

Many health system leaders strive for high performance in management functions like PSRA as much as they do for quality of care. To date however they have had limited practical guidance as to how this might be defined for PSRA or what strategies can be put in place to achieve it. In the work presented here, we have combined a detailed investigation of Canadian healthcare organizations whose leaders are deliberately and thoughtfully trying to achieve excellence, with careful review of the literature. Most importantly, we have identified a framework of elements which are meaningful and tangible to health system managers. They understand how these features affect their ability to achieve high performance and how, within the limits of their mandate and authority, they can address these.The task is large - to combine structures, processes, and behaviours for the desired outcomes - but not beyond reach. 


\section{REFERENCES}

Armstrong, K., C. Mitton, B. Carleton, and J. Shoveller. 2008. Drug formulary decision-making in two regional health authorities in British Columbia, Canada. Health Policy 88(2-3):308-316.

Baker, G.R. and J.-L. Denis. A comparative study of three transformative healthcare systems: lessons for Canada. 2011. Ottawa, ON: Canadian Health Services Research Foundation.

Bate, A., C. Donaldson, and M.J. Murtagh. 2007. Managing to manage healthcare resources in the English NHS? What can health economics teach? What can health economics learn? Health Policy 84(2-3):249-261.

Cohen, D. 1994. Marginal analysis in practice: an alternative to needs assessment for contracting health care. $B M J 309: 781-785$.

Daniels, N. and J. Sabin. Setting limits fairly: can we learn to share medical resources? 2002. Oxford: Oxford University Press.

Dionne, F., Mitton, C., Smith, N., and Donaldson, C. (2009). Evaluation of the impact of Program Budgeting and Marginal Analysis in Vancouver Island Health Authority. Journal of Health Services Research and Policy, 14(4): 234-42.

Donabedian, A. 1988. The quality of care: how can it be assessed? Journal of the American Medical Association 260:1743-8

Donaldson, C., A. Bate, C. Mitton, F. Dionne, and D. Ruta. 2010. Rational disinvestment. QJM: An Internatinal Journal of Medicine 103(10):801-807. doi: 10.193/qjmed/hcq086

Donaldson, C., A. Bate, C. Mitton, S. Peacock, and D. Ruta. 2008. Priority setting in the public sector: turning economics into a management process. In Managing to improve public services, edited by J. Hartley, C. Donaldson, J. Skeltcher, and M. Wallace. Cambridge: Cambridge University Press.

Gibson, J. L., D.K. Martin, and P.A. Singer. 2005a. Evidence, economics and ethics: resource allocation in health services organizations. Healthcare Quarterly 8(2):50-59.

Gibson, J. L., D.K. Martin, and P.A. Singer. 2005b. Setting priorities in health care organizations: criteria, processes and parameters of success. BMC Health Services Research 4:25. doi: $10.1186 / 1472-6963-4-25$

Gibson, J.L., C. Mitton, and G. DuBois-Wing. 2011. Priority setting in Ontario's LHINs: ethics and economics in action. Healthcare Quarterly 14(4):35-43.

Haas, M., J. Hall, R. Viney, and G. Gallego. 2012. Breaking up is hard to do: why disinvestment in medical technology is harder than investment. Australian Health Review 36:148-152.

Hall, W., N. Smith, C. Mitton, J.L. Gibson, and S. Bryan. (2016). An evaluation tool for assessing performance in priority setting and resource allocation: multi-site application to identify strengths and weaknesses. Journal of Health Services Research and Policy 21(1), 15-23. 
Halma, L., C. Mitton, C. Donaldson, and B. West. 2004. Case study on priority setting in rural southern Alberta: keeping the house from blowing in. Canadian Journal of Rural Medicine 9(1):26-36.

Jan, S. 2000. Institutional considerations in priority setting: transactions cost perspective on PBMA. Health Economics 9(7):631-41.

Jan, S. 2003. A perspective on the analysis of credible commitment and myopia in health sector decision making. Health Policy 63:269-278.

Kapiriri, L. and D.K. Martin. 2009. Successful priority setting in low and middle income countries: A framework for evaluation. Health Care Analysis 18:129-147.

Kenny, N. and C. Joffres. 2008. An ethical analysis of international health priority-setting. Health Care Analysis 16: 145-160.

King, N. 2004. Using templates in the thematic analysis of text. In Essential Guide to Qualitative Methods in Organizational Research, edited by C.Cassell and G.Symon. London: Sage.

Lomas, J., G. Veenstra, and J. Woods. 1997. Devolving authority for health care in Canada's provinces: 2. Backgrounds, resources and activities of board members. Canadian Medical Association Journal 156(4):513-520.

McCafferty, S., I. Williams, D. Hunter, S. Robinson, C. Donaldson, and A. Bate. 2012. Implementing world class commissioning competencies. Journal of Health Services Research and Policy 17(Suppl 1):40-48.

Menon, D., T. Stafinski, and D.K. Martin. 2007. Priority-setting for healthcare: who, how, and is it fair? Health Policy 84(2-3):220-233.

Mitton, C., and C. Donaldson. 2004a. Health care priority setting: principles, practice and challenges. Cost Effectiveness and Resource Allocation 2(3). http://www.resourceallocation.com $/$ content $/ 2 / 1 / 3$

Mitton, C., and C. Donaldson. 2004b. Priority setting toolkit: a guide to the use of economics in helathcare decision making. London: BMJ Publishing Group.

Mitton, C., and C. Donaldson. 2003a. Resource allocation in health care: health economics and beyond. Health Care Analysis 11(3):245-57.

Mitton, C., and C. Donaldson. 2003b.Setting priorities and allocating resources in health regions: lessons from a project evaluating program budgeting and marginal analysis. Health Policy 64:335-348.

Mitton, C., and C. Donaldson. 2001. Twenty-five years of program budgeting and marginal analysis in the health sector, 1974-99. Journal of Health Services Research and Policy 6(4):239248. 
Mitton, C., C. Donaldson, H. Waldner, and C. Eagle. 2003. The evolution of PBMA: towards a macro-level priority setting framework for health regions. Health Care Management Science 6:263-269.

Mitton, C. and S. Patten. 2004. Evidence-based priority-setting: what do the decision-makers think? Journal of Heath Services Research and Policy 9(3):146-152.

Mitton, C., S. Patten, and C. Donaldson. 2004. Listening to the decision makers: refinement of macro-level PBMA in Alberta. Applied Health Economics and Health Policy 3(3):143-151.

Mitton, C., N. Smith, S. Peacock, B. Evoy, and J. Abelson. 2009. Public participation in health care priority setting: a scoping review. Health Policy 91(3):219-229.

Mullen, P. 2004. Quantifying priorities in healthcare: transparency or illusion? Health Services Management Research 17(1):47-58.

Peacock, S. An evaluation of program budgeting and marginal analysis applied in South Australian hospitals. 1998. Melbourne: Center for Health Program Evaluation, Monash University.

Peacock, S., C. Mitton, D. Ruta, C. Donaldson, A. Bate, and L. Hedden. 2010. Priority setting in healthcare: towards guidelines for the program budgeting and marginal analysis framework. Expert Rev Pharmacoecon Outcomes Research 10(5):539-552.

Pope C, Ziebland S, Mays N. 2000. Qualitative research in health care: analyzing qualitative data. BMJ 320;114-116.

Robinson, S., H. Dickinson, T. Freeman, B. Rumbold, and I. Williams. 2012a. Structures and processes for priority-setting by health-care funders: a national survey of primary care trusts in England. Health Services Management Research 25:113-130.

Robinson, S., I. Williams, H. Dickinson, T. Freeman, and B. Rumbold, B. 2012b. Prioritysetting and rationing in health care: evidence from the English experience. Social Science and Medicine 75(12), 2386-2393.

Rumrill, P.D. Jr, and S.M. Fitzgerald. 2001. Using narrative literature reviews to build a scientific knowledge base. Work 16:165-170.

Russell, J., Greenhalgh, T., Lewis, H., MacKenzie, I., Maskrey, N., Montgomery, J., O'Donnell, C. 2013. Addressing the 'postcode lottery' in local resource allocation decisions: a framework for clinical commissioning groups. Journal of the Royal Society for Medicine, 106, (4), 120-123.

Ruta, D., C. Mitton, A. Bate, and C. Donaldson. 2005. Programme budgeting and marginal analysis: bridging the divide between doctors and managers. $B M J 330(7506): 1501-1503$. doi: 10.1136/bmj.330.7506.1501

Sabik, L.M., and R.K. Lie. 2008. Priority setting in health care: lessons from the experiences of eight countries. International Journal for Equity in Health 7(4). doi:10.1186/1475-9276-7-4 
Scott, T., R. Mannion, M. Marshall, and H. Davies. 2003. Does organisational culture influence health care performance? A review of the evidence. Journal of Health Services Research and Policy 8(2):105-117.

Sibbald, S.L., P.A. Singer, R. Upshur, and D.K. Martin. 2009. Priority setting: what constitutes success? A conceptual framework for successful priority setting. BMC Health Services Research 9(43). doi:10.1186/1472-6963-9-43

Smith, N., Mitton, C., Bryan, S., Davidson, A., Urquhart, B., Gibson, J.L., Peacock, S., and Donaldson, C. (2013). Decision maker perceptions of resource allocation processes in Canadian health care organizations: a national survey. BMC Health Services Research, 13(247). doi:10.1186/1472-6963-13-247

Stake, R. The art of case research. 1995. Newbury Park, CA: Sage Publications.

Teng, F., C. Mitton, and J. MacKenzie. 2007. Priority setting in the provincial health services authority: survey of key decision makers. BMC Health Services Research 7(84). doi:

10.1186/1472-6963-7-84.

Tsourapas, A. and E. Frew. 2011. Evaluating 'success' in programme budgeting and marginal analysis: a literature review. Journal of Health Services Research and Policy 16(3):177-183.

Yonek, J., S. Hines, and M. Joshi. A Guide to Achieving High Performance in Multi-Hospital Health Systems. 2010. Chicago, IL: Health Research \& Educational Trust. 


\section{TABLE AND FIGURE CAPTIONS}

Table 1: Distribution of Cases

Table 2: Results

Figure 1: Domains of High Performance in PSRA

Sources for Figure 1: Donabedian, 1988; Giddens, 1984; Sanderson, 2001; Scott et al, 2003 
Table 1: Distribution of Cases

\begin{tabular}{|l|c|c|c|}
\hline & $\begin{array}{c}\text { Regional Health } \\
\text { Authorities }\end{array}$ & $\begin{array}{c}\text { Planning \& } \\
\text { Purchasing } \\
\text { Organizations }\end{array}$ & $\begin{array}{c}\text { Tertiary Hospital } \\
\text { Centres }\end{array}$ \\
\hline \$1B+ Budget & A \# & F & D \\
\hline \$500M-\$1B Budget & B & & E \\
\hline $\begin{array}{l}\text { Less than \$500M } \\
\text { Budget }\end{array}$ & C & & \\
\hline
\end{tabular}

\#=previously (i.e., within last 10 years) worked with a member of the research team on PSRA development activities 
Table 2: Results

\begin{tabular}{|c|c|c|}
\hline Element & $\begin{array}{l}\text { Qualitative data from Canadian organizations showing } \\
\text { that healthcare managers see these elements as important } \\
\text { aspects of high performance }\end{array}$ & $\begin{array}{l}\text { The literature shows that the importance of these elements } \\
\text { has been identified in other studies }\end{array}$ \\
\hline \multicolumn{3}{|l|}{ STRUCTURES } \\
\hline $\begin{array}{l}\text { S1: SMT [Senior } \\
\text { Management Team] has } \\
\text { the ability and authority } \\
\text { to move financial } \\
\text { resources within and } \\
\text { across silos. }\end{array}$ & $\begin{array}{l}\text { If the SMT is constrained in its ability to make organization- } \\
\text { wide re-allocations, efficient and ethical distribution of } \\
\text { resources may not be achieved. "If we had more flexibility, } \\
\text { and if the Ministry just held us accountable for outcomes and } \\
\text { didn't put a bunch of other regulations in place, I think it } \\
\text { would be easier to come up with some creative ways of } \\
\text { achieving those targets. ... We work within such a tight } \\
\text { framework that you're really not doing a lot of resource } \\
\text { allocations." (D5, Board member) }\end{array}$ & $\begin{array}{l}\text { Other organizations report ways in which limited authority } \\
\text { negatively impacts PSRA. For example: } \\
\text {-- A budgeting exercise in one Alberta health region had trouble } \\
\text { with resource release due to a lack of authority of participating } \\
\text { managers (Halma et al., 2004). } \\
\text {-- BC's Provincial Health Services Authority was challenged by a } \\
\text { lack of integration across the specialized agencies within the } \\
\text { organization (Teng et al., 2007). }\end{array}$ \\
\hline $\begin{array}{l}\text { S2: Mechanisms are } \\
\text { established for } \\
\text { engagement of staff } \\
\text { (clinical and non- } \\
\text { clinical) in PSRA } \\
\text { decisions, with } \\
\text { particular though not } \\
\text { exclusive attention to } \\
\text { physicians. May include } \\
\text { the use of incentives to } \\
\text { encourage participation. }\end{array}$ & $\begin{array}{l}\text { High performing organizations create structures which enable } \\
\text { staff participation in PSRA. "I think the engagement of our } \\
\text { Middle Management Team works really well. And that's } \\
\text { important, for them to be engaged, because then that actually } \\
\text { helps from a change management perspective" (E3, senior } \\
\text { exec). } \\
\text { Engaging physicians was a pressing concern for healthcare } \\
\text { leaders in case study sites: "We need the chief of service and } \\
\text { the chief of staff sitting around the table when we're } \\
\text { allocating budget. We need them to be involved in terms of } \\
\text { understanding the entire picture not just the physician piece } \\
\text { of that. We need for them to be as concerned about budget as } \\
\text { we are" (C2, senior exec). } \\
\text { Finding workable mechanisms for engagement seems to } \\
\text { become more difficult as one reaches farther from the SMT; } \\
\text { our case study sites readily acknowledged that their staff } \\
\text { engagement does not get down to the 'frontline' employee. }\end{array}$ & $\begin{array}{l}\text { Stakeholder engagement is a frequently noted facilitator for PSRA } \\
\text { (Mitton and Donaldson, 2003b). The importance of engaging with } \\
\text { physicians is argued by many authors (e.g., Robinson et al., } \\
\text { 2012a; Ruta et al., 2005). }\end{array}$ \\
\hline $\begin{array}{l}\text { S3: There is a means to } \\
\text { coordinate priority } \\
\text { setting activity across } \\
\text { all organizational } \\
\text { planning processes }\end{array}$ & $\begin{array}{l}\text { Lack of coordination can be an impediment to good PSRA: } \\
\text { "Our planning cycle doesn 't necessarily line up with the } \\
\text { financial cycle or the budgeting cycle or the Ministry's } \\
\text { introduction of various priorities...." (B1, senior exec) }\end{array}$ & $\begin{array}{l}\text { Recent literature has concluded that PSRA is more than a set of } \\
\text { discrete tools; it should be conceived of as a management process } \\
\text { (Donaldson et al., 2008) which needs to be coordinated with other } \\
\text { management processes that affect resource use. }\end{array}$ \\
\hline
\end{tabular}




\begin{tabular}{|c|c|c|}
\hline $\begin{array}{l}\text { (e.g., strategic planning, } \\
\text { capital projects, } \\
\text { foundation fundraising, } \\
\text { etc.). }\end{array}$ & $\begin{array}{l}\text { Coordination may be facilitated when planned processes of } \\
\text { efficiency seeking and disinvestment become on-going } \\
\text { institutionalized practice, rather than a one-time per year } \\
\text { effort: "[Our PSRA process] is seen as a thing you do at a } \\
\text { certain time of year around certain pockets of money, not a } \\
\text { way of doing business on an everyday basis" (A4, middle } \\
\text { mgr). }\end{array}$ & \\
\hline $\begin{array}{l}\text { S4: There is relative } \\
\text { stability of } \\
\text { organizational structure } \\
\text { and continuity of } \\
\text { personnel. }\end{array}$ & $\begin{array}{l}\text { Continuity and stability were identified in our case studies as } \\
\text { factors contributing to high performance in PSRA. "[CEO] is } \\
\text { pretty fortunate, he's had a very stable team, in terms of } \\
\text { similar people being around for a long time. So, you have } \\
\text { people who know a great deal about the organization, right? } \\
\text { Which, if you turned over half of them, in a short time, I think } \\
\text { it would be difficult" (D4, senior exec). }\end{array}$ & $\begin{array}{l}\text { The facilitating effects of such stability are also widely reported in } \\
\text { the published literature on PSRA performance (e.g., Peacock, } \\
\text { 1998; McCafferty et al., 2012). Stability within senior } \\
\text { management teams has been found to be a common feature } \\
\text { among some exemplary high performing healthcare systems } \\
\text { (Baker and Denis, 2011). }\end{array}$ \\
\hline $\begin{array}{l}\text { S5: Adequate but not } \\
\text { excessive time and } \\
\text { resources are committed } \\
\text { to PSRA. }\end{array}$ & $\begin{array}{l}\text { Careful attention needs to be paid to the time demands of any } \\
\text { PSRA process: "The effort required [in our RA process] is } \\
\text { disproportionate to what I think it should be.... We've not } \\
\text { made the investments in the tools, and so it really makes our } \\
\text { processes and structures work very hard" (B6, senior exec). }\end{array}$ & $\begin{array}{l}\text { Lack of time is a barrier reported in several case studies of PSRA } \\
\text { (e.g., McCafferty et al., 2012; Gibson, Mitton, and DuBois-Wing, } \\
\text { 2011). }\end{array}$ \\
\hline \multicolumn{3}{|l|}{ PROCESSES } \\
\hline $\begin{array}{l}\text { P1: PSRA at the } \\
\text { organization-wide level } \\
\text { is based on economic } \\
\text { and ethical principles. It } \\
\text { includes well-defined, } \\
\text { weighted criteria which } \\
\text { reflect the } \\
\text { organization's values } \\
\text { and strategic priorities; } \\
\text { use of a scoring tool to } \\
\text { operationalize criteria in } \\
\text { ranking individual } \\
\text { proposal; mechanisms } \\
\text { for incorporating best } \\
\text { available evidence; and, } \\
\text { a decision review } \\
\text { mechanism. }\end{array}$ & $\begin{array}{l}\text { All of our case sites used a formal process, whether self- } \\
\text { developed, derived from the literature, or mandated by a } \\
\text { higher order of government. "Part of what we did as well is } \\
\text { develop an ethics framework, both in terms of clinical } \\
\text { decision-making but also on the ethics of resource } \\
\text { allocation.... It made us all think about what are the values.... } \\
\text { it's not just a budgetary decision" (E6, senior exec). } \\
\text { Explicit criteria by which to compare budget alternatives are } \\
\text { an important component of PSRA processes. "I think a high } \\
\text { performance organization is one that is making the most it } \\
\text { can out of the resources it has -- allocating those resources } \\
\text { according to a certain criteria that it has developed internal } \\
\text { to the organization" (C2, senior exec). }\end{array}$ & $\begin{array}{l}\text { Literature contends that a formal, transparent, evidence-based } \\
\text { process lends credibility to decisions (Daniels and Sabin, 2002). } \\
\text { Since PSRA choices are inherently value laden, both ethical and } \\
\text { economic principles should be incorporated (Gibson, Mitton, and } \\
\text { DuBois-Wing, 2011; Kenny and Joffres, 2008). } \\
\text { According to the literature, "the choice of criteria is probably the } \\
\text { most important influence on the resulting prioritization of } \\
\text { options" (Mullen, 2004, p. 53). Such criteria must be specific } \\
\text { enough to distinguish among different options (Dionne et al, } \\
\text { 2009). Having a formal tool (e.g., one that is based on assigning } \\
\text { points to proposals based on criteria) forces the consistent } \\
\text { application of criteria - otherwise, criteria may simply be } \\
\text { considered implicitly (Mitton, Patten, and Donaldson, 2004). }\end{array}$ \\
\hline $\begin{array}{l}\text { P2: SMT ensures } \\
\text { effective } \\
\text { communication (both }\end{array}$ & $\begin{array}{l}\text { Our respondents described a range of methods which they } \\
\text { used, from direct face-to-face interaction to print or electronic } \\
\text { one-way dissemination of information. "Communication has }\end{array}$ & $\begin{array}{l}\text { Many instances in the literature describe how healthcare decision } \\
\text { makers have recognized improved communications as a means to } \\
\text { strengthen their PSRA processes (e.g., Robinson et al, 2012b). }\end{array}$ \\
\hline
\end{tabular}




\begin{tabular}{|c|c|c|}
\hline $\begin{array}{l}\text { internally and } \\
\text { externally) around its } \\
\text { priority setting and } \\
\text { resource allocation -- } \\
\text { leading to transparency. }\end{array}$ & $\begin{array}{l}\text { become very high profile. We try very hard to communicate in } \\
\text { all different ways and fashions to the various groups" (E5, } \\
\text { senior exec). }\end{array}$ & $\begin{array}{l}\text { Communication pays off, among other reasons, if it serves "to } \\
\text { minimize efforts spent on defending decisions when media reports } \\
\text { over the denial of a service to a patient reach an otherwise } \\
\text { unaware public" (Menon, Stafinsi, and Martin, 2007, p. 232). }\end{array}$ \\
\hline $\begin{array}{l}\text { P3: Skill development } \\
\text { for PSRA occurs } \\
\text { throughout the } \\
\text { organization including } \\
\text { managers, directors, } \\
\text { senior executive and } \\
\text { clinical leaders. }\end{array}$ & $\begin{array}{l}\text { Our case study sites were tackling this challenge: "There's } \\
\text { been a lot of education, some education last year and more } \\
\text { scheduled for this year to bring more people into the know } \\
\text { about what is [our PSRA process]." (A4, middle mgr) }\end{array}$ & $\begin{array}{l}\text { Managers in other organizations have indicated that, in order from } \\
\text { them to adjust to new PSRA processes, some sort of education or } \\
\text { training is needed (Mitton, Donaldson, Waldner et al., 2003). } \\
\text { Such skill development and capacity building creates greater buy- } \\
\text { in to and acceptance for explicit PSRA (Teng et al., 2007). While } \\
\text { infrequently reported in detail, cases in the literature find the } \\
\text { training experience of managers generally positive (Cohen 1994). }\end{array}$ \\
\hline $\begin{array}{l}\text { P4: Follow through on } \\
\text { decisions -- SMT puts } \\
\text { in place appropriate } \\
\text { change management } \\
\text { strategies, with } \\
\text { performance } \\
\text { measurement, tracking } \\
\text { of outcomes, and } \\
\text { responds as needed. }\end{array}$ & $\begin{array}{l}\text { Lack of follow up is a barrier to high performance. "There's a } \\
\text { general feeling that we don't drive to execution as well as we } \\
\text { can. We make decisions, but somehow we don't close well. } \\
\text { We make the decisions as senior management, we go forward, } \\
\text { but then, how it flows through to the end kind of gets lost in } \\
\text { the fog of our day-to-day existences" (D4, senior exec). Some } \\
\text { informants suggested that PSRA innovations established } \\
\text { previously had not been maintained in practice. }\end{array}$ & $\begin{array}{l}\text { PSRA literature has tended to focus on the development, } \\
\text { refinement and application of decision support tools (Donaldson } \\
\text { et al., 2008). There has been relatively little study of whether such } \\
\text { changes to practice are sustained over time; this would be desired } \\
\text { as it shows 'credible commitment' (Jan, 2003) on the part of SMT } \\
\text { to the PSRA process. }\end{array}$ \\
\hline $\begin{array}{l}\text { P5: A skilled internal } \\
\text { project coordinator has } \\
\text { responsibility for } \\
\text { overseeing the } \\
\text { organization-wide } \\
\text { PSRA effort. }\end{array}$ & $\begin{array}{l}\text { The idea appears in our case study data: "A point-person is } \\
\text { important... It allowed that senior coordination, } \\
\text { standardization. You start to develop an internal expertise, a } \\
\text { concentration on it. You develop a history of the proposals } \\
\text { that came before" (A5, middle mgr). }\end{array}$ & $\begin{array}{l}\text { The importance of a dedicated project coordinator has been noted } \\
\text { in the literature (Gibson, Mitton, and DuBois-Wing, 2011; Mitton } \\
\text { and Donaldson, 2003b). }\end{array}$ \\
\hline \multicolumn{3}{|c|}{ ATTITUDES AND BEHAVIOURS } \\
\hline $\begin{array}{l}\text { A1: Working } \\
\text { relationships within the } \\
\text { SMT are respectful and } \\
\text { characterized by jointly } \\
\text { addressing challenges, } \\
\text { mutual trust, honesty, } \\
\text { and the open and frank } \\
\text { exchange of views. }\end{array}$ & $\begin{array}{l}\text { One of our respondents described the difference between the } \\
\text { current management team and a predecessor organization: } \\
\text { "We didn't really respect each other. You couldn't trust the } \\
\text { other person. Whatever they said, you had to say, 'Okay. } \\
\text { What are they really going to do next?' And it was a bit of a } \\
\text { game, right? I'd leave a meeting and say, 'Okay. What's he } \\
\text { going to do now?'" (D8, senior exec). } \\
\text { As suggested in another organization, "I think if the priority } \\
\text { setting is done really well, and you have a culture of support, } \\
\text { a good way of working together, then your resource } \\
\text { allocation itself can actually be less perfect" (B6, senior }\end{array}$ & $\begin{array}{l}\text { Jan (2000) argues that successful PSRA practice "relies heavily } \\
\text { on the goodwill of participants in providing realistic assessment } \\
\text { of expected benefit" (633). Things break down if there is } \\
\text { extensive "gaming to overstate the benefits lost through cuts, and } \\
\text { to overstate the benefits gained through increments in resources" } \\
\text { (Jan, 2000, 635). Lack of trust is a key barrier to success in PSRA } \\
\text { (Mitton and Donaldson, 2004a). }\end{array}$ \\
\hline
\end{tabular}




\begin{tabular}{|c|c|c|}
\hline & exec). & \\
\hline $\begin{array}{l}\text { A2: There is a culture of } \\
\text { improvement. The SMT } \\
\text { strives for excellence, } \\
\text { and is willing to seek } \\
\text { out and learn from what } \\
\text { peers and leading } \\
\text { organizations are doing. }\end{array}$ & $\begin{array}{l}\text { A culture of improvement involves striving for excellence: } \\
\text { "What makes you a high performer is that you're always } \\
\text { driven by what's the best, what's the best, what's the best. The } \\
\text { whole pursuing of excellence is your driver. If you're going to } \\
\text { do something, it takes as much time to do something to be } \\
\text { mediocre as it takes to be excellent, but it's much more fun to } \\
\text { be excellent" (D3, senior exec). } \\
\text { Culture of improvement is also demonstrated through } \\
\text { investment in supports around data collection, process } \\
\text { management and team-building, even when such efforts } \\
\text { appear to divert money from direct patient care to the } \\
\text { 'administration' lines of the budget. (D, comment observed at } \\
\text { management meeting). }\end{array}$ & $\begin{array}{l}\text { The PSRA literature makes similar claims. Teng et al (2007) } \\
\text { report that an existing culture of learning was perceived by } \\
\text { managers to facilitate PSRA in their organization; see also } \\
\text { Peacock, 1998; Mitton and Donaldson, 2004a. } \\
\text { Benchmarking performance against objective standards is a key } \\
\text { feature of high performance in delivering quality healthcare } \\
\text { (Yonek, Hines, and Joshi, 2010). Decision makers have indicated } \\
\text { that this applies to PSRA as well: "Managers and clinicians very } \\
\text { clearly stated that ... if information is used to indicate that their } \\
\text { practice differs from other like regions, re-allocation would be } \\
\text { pursued" (Mitton and Donaldson, 2003a, p. 253). }\end{array}$ \\
\hline $\begin{array}{l}\text { A3: Decisions are made } \\
\text { with a system-wide } \\
\text { perspective and a view } \\
\text { to their long-term } \\
\text { strategic alignment } \\
\text {--Senior leaders adopt a } \\
\text { system-wide point of } \\
\text { view while considering } \\
\text { how decisions will be } \\
\text { experienced across } \\
\text { Departments and over a } \\
\text { multi-year timeframe. } \\
\text {--SMT is willing to look } \\
\text { beyond incremental } \\
\text { spend to re-assess base } \\
\text { budgets, i.e., to pursue } \\
\text { marginal analysis and } \\
\text { disinvestment } \\
\text { opportunities }\end{array}$ & $\begin{array}{l}\text { "To me, one characteristic of a high-performing organization } \\
\text { is that the decision-making process takes a systems-wide } \\
\text { perspective and recognizes that decisions made in one part of } \\
\text { the organization affect many other parts of the organization." } \\
\text { (A-3, senior exec) } \\
\text { This attitude is crystallized in the choice to implement } \\
\text { particular procedures for PSRA: "We've been able to refine a } \\
\text { bit over the last year, to say that if what you're putting forth } \\
\text { in your briefing note interfaces with other departments, you } \\
\text { have to be able to do that work before you bring it to the } \\
\text { team. You can't just say you're going to do this and that } \\
\text { involves something from [a different Department] unless } \\
\text { you've had that discussion, it's their priority as well" (C5, } \\
\text { senior exec). } \\
\text { High performance will not be achieved without looking } \\
\text { closely at the allocation of all budgeted funds: "Our funding } \\
\text { allocation decisions are basically focused on incremental } \\
\text { pressures, right? So we don't ask ourselves the question, if we } \\
\text { get a } 10 \% \text { funding increase, the 90\% that's available to us, } \\
\text { are we spending that wisely? I don't think we look hard } \\
\text { enough at that part of it" (B3, senior exec). }\end{array}$ & $\begin{array}{l}\text { The meaning of disinvestment has been much debated in PSRA } \\
\text { literature. While some see it primarily as the elimination of } \\
\text { services or technologies that are proven not to be effective (Haas } \\
\text { et al., 2012), sometimes efficiency gains can only be achieved by } \\
\text { redistributing resources from effective programs to other effective } \\
\text { but more highly valued programs (Donaldson et al., 2010). } \\
\text { Several studies have reported how PSRA efforts falter when it } \\
\text { comes to managers' willingness to propose disinvestments (e.g., } \\
\text { Robinson et al., 2012a). }\end{array}$ \\
\hline $\begin{array}{l}\text { A4: Fit of priority } \\
\text { setting decisions with }\end{array}$ & $\begin{array}{l}\text { Case study sites concurred that they could do better in public } \\
\text { engagement: "I do think the area that we need to improve on }\end{array}$ & $\begin{array}{l}\text { According to the PSRA literature, "it is now generally accepted } \\
\text { that the public should have a real influence on how ... choices are }\end{array}$ \\
\hline
\end{tabular}




\begin{tabular}{|c|c|c|}
\hline $\begin{array}{l}\text { social and community } \\
\text { values is sought. Public } \\
\text { participation and input } \\
\text { is valued; it is } \\
\text { integrated into decisions } \\
\text { in meaningful ways; } \\
\text { consideration is given to } \\
\text { how decisions align } \\
\text { with external partners } \\
\text { and the larger health } \\
\text { system }\end{array}$ & $\begin{array}{l}\text { is the whole involvement of the community in decision } \\
\text { making.... Real discussions that actually would lead to them } \\
\text { having input into things like budget allocation" (C2, senior } \\
\text { exec). }\end{array}$ & $\begin{array}{l}\text { made" (Sabik and Lie, 2008). Nonetheless, a wide-ranging review } \\
\text { found that organizations struggle with how to incorporate the } \\
\text { public in PSRA decisions (Mitton et al., 2009). Where it has been } \\
\text { directly studied, managers express support for public input about } \\
\text { the broad social values which should govern resource allocation, } \\
\text { while not necessarily asking the public to play a direct role in } \\
\text { deciding between particular program and service options } \\
\text { (e.g.,Kapiriri and Martin, 2009). }\end{array}$ \\
\hline $\begin{array}{l}\text { A5: SMT displays } \\
\text { strong leadership for } \\
\text { PSRA-SMT is aware } \\
\text { of and manages the } \\
\text { external environment } \\
\text { and other constraining } \\
\text { factors, and is willing to } \\
\text { take and stand behind } \\
\text { tough decisions. }\end{array}$ & $\begin{array}{l}\text { For Canadian healthcare organizations, provincial ministries } \\
\text { as funders are perhaps the most important external } \\
\text { stakeholder: "We go through quite a rigorous process every } \\
\text { year in terms of submitting our priorities and our global } \\
\text { budget plan to the Ministry. ... certainly we use [PSRA } \\
\text { process] as our rationale with the Ministry for making } \\
\text { decisions" (A4, middle mgr). } \\
\text { Our case site respondents insisted however that they would } \\
\text { not let their knowledge of provincial preferences undermine } \\
\text { their own commitment to follow what they thought the best } \\
\text { approach to PSRA: "We try to stay as true as we can to our } \\
\text { process and let the political lenses be applied by the political } \\
\text { people. We could probably figure it out and it wouldn't be } \\
\text { very many changes. But that's not a path we've gone down" } \\
\text { (C5, senior exec) }\end{array}$ & $\begin{array}{l}\text { Being able to anticipate and deal with external factors could } \\
\text { certainly be an asset. Baker and Denis (2011) state that, "an } \\
\text { important part of the success for [three recognized high- } \\
\text { performing healthcare] systems has come from their ability to } \\
\text { identify larger forces that shaped their environments and to } \\
\text { respond effectively to these forces" (p. 19). Having a formal } \\
\text { PSRA process can provide a bulwark for managers to resist such } \\
\text { demands (Armstrong et al., 2008). } \\
\text { Peacock et al. (2010) argue that priority setting is unlikely to } \\
\text { succeed without effective leaders. }\end{array}$ \\
\hline \multicolumn{3}{|l|}{ OUTCOMES } \\
\hline $\begin{array}{l}\text { O1: Actual reallocation } \\
\text { of financial resources is } \\
\text { achieved }\end{array}$ & [Not coded in our qualitative data.] & $\begin{array}{l}\text { Actual resource allocation has been identified as a possible } \\
\text { measurable outcome of priority setting by many authors (e.g., } \\
\text { Gibson, Martin, and Singer, 2005b; Sibbald et al., 2009). Formal } \\
\text { processes like Program Budgeting and Marginal Analysis, or } \\
\text { PBMA, have been shown to achieve this: a review of experiences } \\
\text { from the 1970s through 1990s found 59\% of cases report that } \\
\text { priorities were set or resources actually reallocated (Mitton and } \\
\text { Donaldson, 2001). Tsourapas and Frew (2011) conclude in an } \\
\text { updated review that almost half of published PBMA studies found } \\
\text { that disinvestment or reallocation was achieved. }\end{array}$ \\
\hline O2: The process has the & We heard this from one case study respondent, pointing to & Sibbald et al. (2009) identify stakeholder endorsement and \\
\hline
\end{tabular}




\begin{tabular}{|c|c|c|}
\hline $\begin{array}{l}\text { understanding and } \\
\text { endorsement of key } \\
\text { internal and external } \\
\text { stakeholders (e.g., } \\
\text { Board of Directors, staff } \\
\text { and medical leadership, } \\
\text { Ministry, public). }\end{array}$ & $\begin{array}{l}\text { where such understanding was lacking: "It would be } \\
\text { beneficial for us to have more, better understanding of the } \\
\text { deliberations and the systems used by the leadership team to } \\
\text { come to the allocation of resources that they bring to us for } \\
\text { approval..." (D11, Board member). }\end{array}$ & $\begin{array}{l}\text { support as an outcome of successful priority setting. As reported } \\
\text { in the literature, this is a key concern of senior managers } \\
\text { elsewhere: "I think fundamentally we have to have } 100 \text { percent } \\
\text { commitment from the board and CEO. It's always the same. If } \\
\text { they're not really committed to [it], then it's probably not going to } \\
\text { be well endorsed" (Teng et al., 2007). }\end{array}$ \\
\hline $\begin{array}{l}\text { O3: There is greater } \\
\text { understanding among } \\
\text { participants of the } \\
\text { organization as a whole, } \\
\text { and of PSRA practice. }\end{array}$ & $\begin{array}{l}\text { High performance PSRA should generate greater } \\
\text { understanding of the entire organization among all } \\
\text { participants through discussion and evaluation of proposals } \\
\text { from across the organization. "I don't need to know every } \\
\text { detail about [VP]'s portfolio, but I need to understand enough } \\
\text { to understand what the strategies are and why they're } \\
\text { important" (B1, senior exec). }\end{array}$ & $\begin{array}{l}\text { Mitton and Patton (2004) report that managers in Calgary saw } \\
\text { learning about other areas within the organization as one of the } \\
\text { benefits of their experience. It forms one of the outcome } \\
\text { dimensions in Sibbald et al (2009). }\end{array}$ \\
\hline $\begin{array}{l}\text { O4: Resource allocation } \\
\text { decisions are justified in } \\
\text { light of the } \\
\text { organization's core } \\
\text { values. Progress is } \\
\text { made toward strategic } \\
\text { objectives. Improved } \\
\text { health (broadly defined) } \\
\text { is achieved as a result of } \\
\text { decisions made through } \\
\text { the RA process. High } \\
\text { quality care is } \\
\text { delivered. }\end{array}$ & $\begin{array}{l}\text { A high performing health organization with respect to PSRA } \\
\text { should be maximizing health gain for the community it } \\
\text { serves. "Are we spending money in areas that are not } \\
\text { contributing or adding value to our core purpose, which is } \\
\text { serving patients? We don't ask ourselves those hard questions } \\
\text { well" (B3, senior exec). } \\
\text { A useful proxy for longer term outcomes may be whether } \\
\text { PSRA choices cohere with an organization's values and } \\
\text { strategic objectives. } \\
\text { "We have decided as an organization, a senior management } \\
\text { team ... that these are the core values of what we're trying to } \\
\text { do as an organization; if it aligns with that, that's a } \\
\text { success... If it's not in with one of these strategic priorities, } \\
\text { we probably shouldn't even have been looking at it in the first } \\
\text { place" (E1, senior exec). }\end{array}$ & $\begin{array}{l}\text { There is some controversy about the extent to which PSRA } \\
\text { processes can be held accountable for this outcome, given great } \\
\text { difficulties in attribution (Sibbald et al., 2009). Strong, } \\
\text { organization-wide adherence to strategic directions is argued in } \\
\text { the literature to be a key feature of high performance in other } \\
\text { areas, like patient care: having "a system-wide strategic plan for } \\
\text { quality and safety with measurable goals across multiple } \\
\text { dimensions is a best practice for improving system performance" } \\
\text { (Yonek, Hines and Joshi, 2010, p. 2). }\end{array}$ \\
\hline
\end{tabular}




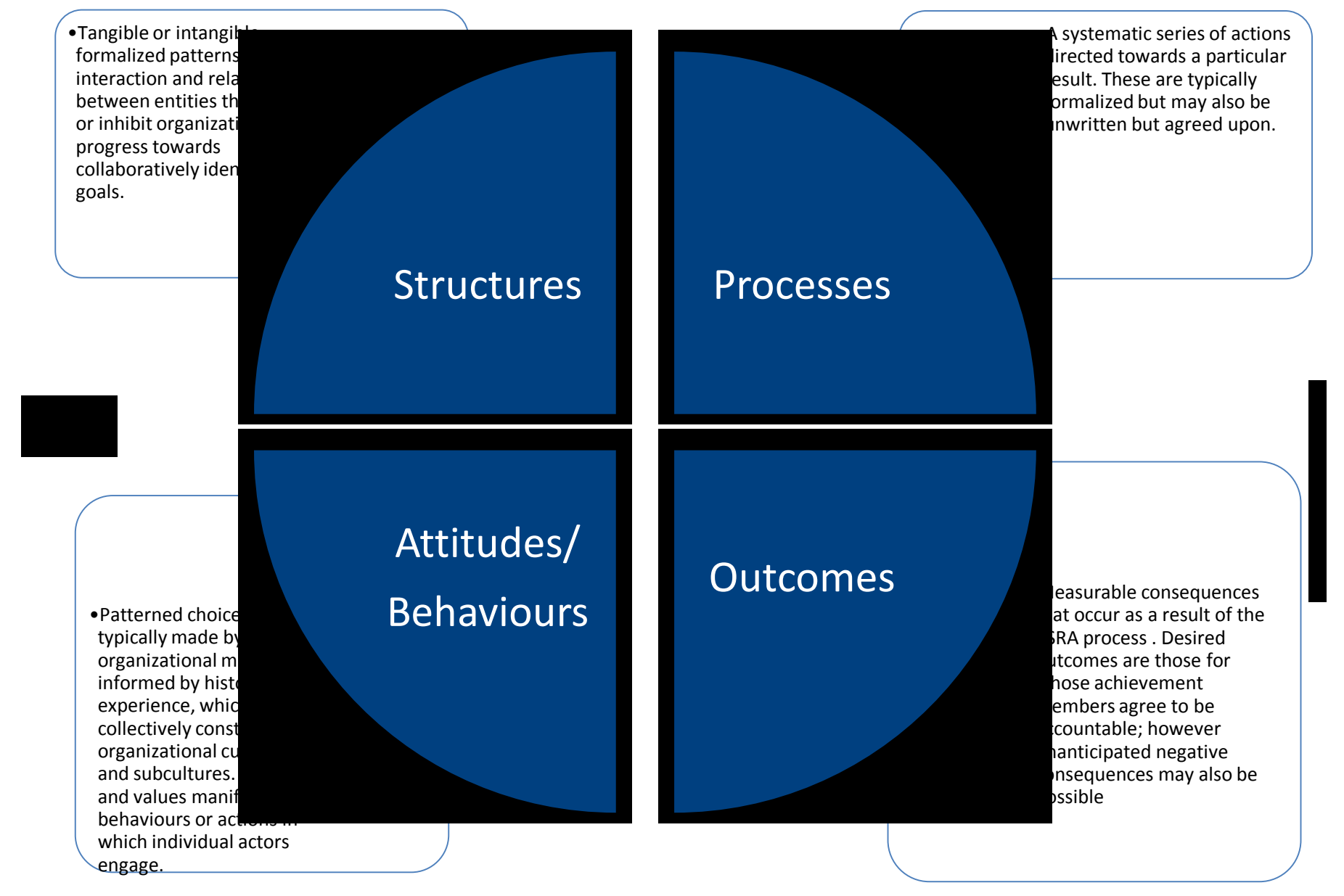




\title{
Supplemental File One: Notes on Terminology
}

\begin{abstract}
What do we mean by 'Priority Setting' and 'Resource Allocation' (PSRA)?
Kenny and Joffres note that "while priority setting and resource allocation are often conflated, they are distinct but related process" (2008, p. 146). Priorities are those areas which the organization deems most important to act on. While sometimes these can be addressed with minimal resources, often it is the decision about where to allocate funding that makes priorities concrete. Contra Kenny and Joffres, we would emphasise the relatedness rather than the distinctiveness of these concepts. For convenience, then, we use the umbrella term priority setting and resource allocation, or PSRA, throughout this paper.
\end{abstract}

\section{What is 'High Performance' in PSRA?}

High performance (Baker et al., 2008; Yonek, Hines, and Joshi, 2010) has much in common with concepts like successful, or effective, or good quality, but we believe it connotes a more expansive idea and implies greater attention to a larger body of contextual conditions related to how well organizational management performs its core functions; thus it is the term we adopt here. The framework advanced here, as a whole, constitutes our working definition of high performance in PSRA. As described in more detail in the text, high performance consists of both putting in place appropriate structures and processes, as well as in the outcomes that are achieved by PSRA efforts.

What do we mean by ‘Region'?

The concept of 'region' has always been fundamentally contested in Canadian politics and policy analysis (Bickerton, 1999). Depending on one's purpose, a region may be defined according to population size, economic base, shared history and institutional development, cultural and linguistic similarities, and/or popular perception. An individual province may or may not be considered as a distinct region. While not the only possible categorization, the one we use here is common (Brooks, 2004).

\section{References}

Baker, G.R., A. MacIntosh-Murray, C. Porcellato, L. Dionne, K. Stelmacovich, and K. Born. High performing healthcare systems: delivering quality by design. 2008. Toronto, ON:

Longwoods Publishing Corporation.

Bickerton, J. 1999. Regionalism in Canada. In Canadian Politics 3rd Edition, edited by J.

Bickerton and A.-G. Gagnon. Peterborough, ON: Broadview Press Ltd. 
Brooks, S. Canadian democracy: an introduction 4th edition. 2004. Don Mills, ON: Oxford University Press.

Kenny, N. and C. Joffres. 2008. An ethical analysis of international health priority-setting. Health Care Analysis 16: 145-160.

Yonek, J., S. Hines, and M. Joshi. A Guide to Achieving High Performance in Multi-Hospital Health Systems. 2010. Chicago, IL: Health Research \& Educational Trust. 


\section{Supplemental File Two: Extended Description of Research Methodology}

Case Site Selection: Participants in an earlier national survey of senior decision makers nominated organizations they considered to be "high performers in priority setting and resource allocation". The most common reasons for nomination included: existence of a formal and explicit resource allocation process, ability to link the process to outcomes and to foster change, evidence of stakeholder engagement, and the use of an ethical lens to assess resource allocation options (Smith et al., 2014). These names were vetted by an Expert Panel consisting of six CEOs from Canadian healthcare organizations who added further suggestions based on their own knowledge. From this list, we identified two possible study sites in each of six 'regions' in Canada: British Columbia, the Prairies, Ontario, Quebec, the Atlantic provinces, and the North. One site from each region was initially selected by the research team. A senior management team (SMT) member in each site was approached informally, where possible by a member of the Expert Panel known to them, to inquire if the organization would be receptive to participating. Two sites declined our initial invitation, leaving the team to approach two further organizations, both of which accepted.

Case Site Data Collection: A key contact at each site (in all cases, the Executive Assistant to the CEO or another Senior Management Team (SMT) member) recruited participants on behalf of the researchers. Interviewees included SMT members, Board members, and middle managers. Obtaining the perspectives of middle managers and Board members allowed us to see if these corroborated the senior management self-reports. In total we conducted 33 interviews with SMT members and 5 interviews with board members; 24 middle managers took part in individual (4) or group (20) interviews. Since each site had responsibility for identifying and contacting respondents, we lack consistent information needed to calculate an overall response rate. Across sites, an average of $95 \%$ of scheduled interviews could be completed (range, $86 \%$ to $100 \%$ ).

Table S1: Case study site descriptions and data collected

\begin{tabular}{|c|l|l|l|}
\hline Site & \multicolumn{1}{|c|}{ Description } & \multicolumn{1}{|c|}{ Data collected } & $\begin{array}{c}\text { Uptake Rate among Key } \\
\text { Contacts invited to } \\
\text { participate }\end{array}$ \\
\hline A & $\begin{array}{l}\text { A Regional Health Authority. Serves a } \\
\text { population of over a million with many } \\
\text { new Canadians. Annual operating } \\
\text { budget of between \$1-3 billion dollars. } \\
\text { Predominantly urban/suburban with } \\
\text { some outlying rural areas. At the time } \\
\text { of research, this site was using a form } \\
\text { of organization-wide PBMA (Peacock } \\
\text { et al, 2010). }\end{array}$ & $\begin{array}{l}\text { Individual interviews with 4 vice- } \\
\text { presidents and 1 Board member. } \\
\text { Group interview with 4 middle } \\
\text { managers. }\end{array}$ & $100 \%$ \\
\hline B & $\begin{array}{l}\text { A Regional Health Authority. Serves a } \\
\text { population of between 200,000 and }\end{array}$ & $\begin{array}{l}\text { Individual interviews with 6 vice } \\
\text { presidents. }\end{array}$ & $86 \%$ \\
\hline
\end{tabular}




\begin{tabular}{|c|c|c|c|}
\hline & $\begin{array}{l}300,000 \text {. Annual operating budget less } \\
\text { than } \$ 1 \mathrm{~B} \text {. Consists of an urban core } \\
\text { with surrounding rural areas. At the } \\
\text { time of research, PSRA in this } \\
\text { organization was being guided by Lean } \\
\text { management approaches (Poksinska, } \\
\text { 2010). }\end{array}$ & & \\
\hline $\mathrm{C}$ & $\begin{array}{l}\text { A Regional Health Authority. Serves a } \\
\text { population of slightly less than } 100,000 \text {, } \\
\text { older than the Canadian average. } \\
\text { Annual operating budget of } \\
\text { approximately } \$ 250 \text { million. A } \\
\text { predominantly rural area with many } \\
\text { small and widely-separated } \\
\text { communities. This organizing was } \\
\text { using an explicit formal PSRA process } \\
\text { and criteria which had been developed } \\
\text { internally. }\end{array}$ & $\begin{array}{l}\text { Individual interviews with CEO, } 3 \\
\text { vice presidents, } 4 \text { middle managers, } \\
\text { and } 1 \text { Board member. Group } \\
\text { interview with } 8 \text { middle managers. }\end{array}$ & $92 \%$ \\
\hline $\mathrm{D}$ & $\begin{array}{l}\text { An accredited Academic Health Centre } \\
\text { and tertiary referral hospital operating } \\
\text { several sites. Serves a local population } \\
\text { of over } 1 \text { million. Annual operating } \\
\text { budget of over } \$ 1 \text { billion. } \\
\text { Predominantly urban. PSRA processes } \\
\text { in this organization had previously been } \\
\text { developed using the A4R framework } \\
\text { (Daniels and Sabin, 2002) which } \\
\text { though no longer explicitly cited still } \\
\text { informed key practices. }\end{array}$ & $\begin{array}{l}\text { Individual interviews with CEO, } \\
\text { Chief of Medicine, } 7 \text { vice } \\
\text { presidents, and } 2 \text { Board members. } \\
\text { Group interviews with middle } \\
\text { managers }(n=8)\end{array}$ & $91 \%$ \\
\hline $\mathrm{E}$ & $\begin{array}{l}\text { An accredited tertiary referral hospital, } \\
\text { serving both local population of } 20,000 \\
\text { and several scattered, remote } \\
\text { communities often accessible by air } \\
\text { only. Many aboriginal language and } \\
\text { culture groups. Annual operating } \\
\text { budget of over } \$ 100 \text { million. At the } \\
\text { time of the research, this site employed } \\
\text { an internally developed ethics } \\
\text { framework to guide PSRA practices at } \\
\text { the senior management level. }\end{array}$ & $\begin{array}{l}\text { Individual interviews with CEO, } 4 \\
\text { vice presidents, and } 1 \\
\text { representative of the } \\
\text { provincial/territorial department of } \\
\text { health. }\end{array}$ & $100 \%$ \\
\hline $\mathrm{F}$ & $\begin{array}{l}\text { A regional planning and funding } \\
\text { agency which allocates money to } \\
\text { providers across a range of community } \\
\text { and acute care services. Annual } \\
\text { operating budget of between } \$ 500 \\
\text { million and } \$ 1 \mathrm{~B} \text { and a population of } \\
\text { around } 300,000 \text { people, equally divided } \\
\text { between urban and rural areas. This site } \\
\text { conducted extensive discussion and } \\
\text { interaction in PSRA but did not employ } \\
\text { a clearly-defined formal approach. }\end{array}$ & $\begin{array}{l}\text { Individual interviews with } \mathrm{CEO} \text { and } \\
4 \text { other members of the senior } \\
\text { management team. }\end{array}$ & $100 \%$ \\
\hline
\end{tabular}


Literature Review: The research team began its literature review with a small set of key articles known to the authors (Bate, Donaldson, and Murtagh, 2007; Gibson, Martin, and Singer, 2005b; Kapiriri and Martin, 2009; Mitton \& Donaldson, 2003a; Peacock, 1998; Sibbald et al, 2009), who collectively have an extensive research history in this field. Other reviews have successfully begun from such point (e.g., Riley, Norman, and Best, 2012). Our inclusion criteria were that papers discussed empirical studies of healthcare PSRA efforts, and attempted to assess or evaluate the outcomes of such efforts. Relevant articles from their reference lists were retrieved and reviewed; citations of the seminal articles were also identified. Test keyword searches on different databases determined that MedLine best captured the seed articles and their references, so this database was used as a supplemental source. The MedLine search encompassed the years 1993-2012, capturing the period of greatest growth in PSRA research in the health field. Literature review was thus iterative; for instance, we ran secondary searches around such concepts as leadership and public participation as these began to emerge prominently from analysis of interview responses. Given this, we cannot readily report summary statistics from the literature review; articles were read repeatedly and some which might not initially have seemed relevant consequently became so as new themes, additional elements of high performance in PSRA, emerged from our case studies.

Template Analysis: Template analysis is a semi-structured approach to qualitative data analysis (King, 2004). Researchers apply a set of pre-existing codes to their data, sorting key statements into the relevant categories "before proceeding to the connecting and corroborating/legitimating phases of the analysis" (Crabtree and Miller, 1999, p. 165).

Probably the best known and most widely used model of healthcare quality - Structure-ProcessOutcome (Donabedian, 1988; Mark et al, 1997) - was our starting point in developing an organizing framework for the data. We judged that the concepts of this model could reasonably be applied to investigate high performance in PSRA. Health organizations and systems consist of relatively stable structures, including types of personnel, tools, and material resources. Within this framework, managers, providers and other staff operationalize processes or sequences of actions, which can be more or less formally specified, to accomplish desired outcomes -in our context, these processes and outcomes relate in particular to PSRA. In addition, we know that the achievement of outcomes within particular settings is mediated by individual and group agency; structures influence what is possible at any given time, but they are also amenable to change through deliberate and directed effort (Giddens, 1984). As Sanderson (2001) argues in the context of local government, successful performance depends upon instilling "an appropriate 'culture' ... not simply on putting in place structures, systems and processes" (p. 311). To capture this and the explicit role of organizational culture (Scott et al., 2003), we added a domain of Attitudes/Behaviours. 
Inductive analysis: In the inductive analysis, three types of coding were performed (Strauss and Corbin, 1990). First, open coding: statements about organization-wide PSRA were compared and given conceptual labels to develop themes. Next, through axial coding, we placed these themes within a relevant domain. Finally, we used selective coding to refine poorly developed categories by revisiting the data, further searching the literature, and in some instances returning to the field to collect additional data. The technique of constant comparison was applied throughout (Strauss and Corbin, 1990): we compared statements to each other in order to classify them, and also made comparisons to cases described in the literature and the researchers' own experiences in order to better understand the properties of each domain and element. Regular discussions among team members critiqued and ultimately confirmed the emerging themes.

References

Crabtree, B.F. and W.L. Miller. 1999. Using codes and code manuals: a template organizing style of interpretation. In Doing Qualitative Research 2nd Edition, edited by B.F. Crabtree and W.L. Miller. Thousand Oaks, CA: Sage Publications.

Daniels, N. and J. Sabin. Setting limits fairly: can we learn to share medical resources? 2002. Oxford: Oxford University Press.

Donabedian, A. 1988. The quality of care: how can it be assessed? Journal of the American Medical Association 260:1743-8

Giddens, A. The constitution of society: Outline of the theory of structuration. 1984. Cambridge: Polity Press.

King, N. 2004. Using templates in the thematic analysis of text. In Essential Guide to Qualitative Methods in Organizational Research, edited by C.Cassell and G.Symon. London: Sage.

Mark, B. A., J. Salyer, and N. Geddes. 1997. Outcomes research. Clues to quality and organizational effectiveness? The Nursing clinics of North America 32(3):589-601.

Peacock, S., C. Mitton, D. Ruta, C. Donaldson, A. Bate, and L. Hedden. 2010. Priority setting in healthcare: towards guidelines for the program budgeting and marginal analysis framework. Expert Rev Pharmacoecon Outcomes Research 10(5):539-552.

Poksinska, B. 2010. The current state of Lean implementation in health care: literature review. Quality Management in Health Care 19(4):319-329.

Riley, B., C.D. Norman, and A. Best. 2012. Knowledge integration in public health: a rapid review using systems thinking. Evidence \& Policy 8(4):417-431.

Sanderson, I. 2001. Performance management, evaluation and learning in 'modern' local government. Public Administration 79(2):297-313. 
Scott, T., R. Mannion, M. Marshall, and H. Davies. 2003. Does organisational culture influence health care performance? A review of the evidence. Journal of Health Services Research and Policy 8(2):105-117.

Smith, N., W. Hall, C. Mitton, S. Bryan, and B. Urquhart. (2014). What constitutes high performance in priority setting and resource allocation? Decision maker narratives identified from a survey and qualitative study in Canadian healthcare organizations. Health Services Management Research 27(3-4), 49-56.

Strauss, A. and J. Corbin. Basics of qualitative research: grounded theory procedures and techniques. 1990. Newbury Park, CA: Sage Publications. 
Supplemental File Three: Additional Comments related to the Elements of High Performance

\begin{tabular}{|c|c|}
\hline Element & Additional Comments \\
\hline STRUCTURES & STRUCTURES \\
\hline $\begin{array}{l}\text { S1: SMT [Senior } \\
\text { Management Team] } \\
\text { has the ability and } \\
\text { authority to move } \\
\text { financial resources } \\
\text { within and across silos. }\end{array}$ & $\begin{array}{l}\text { Certain conditions seem more conductive to re-allocation decisions. Global budgets } \\
\text { rather than designated envelopes are one structural feature which seems suited to } \\
\text { maximizing autonomy (Mitton and Donaldson, 2004a). The broader lens brought by } \\
\text { the creation in most Canadian provinces of integrated health organizations (RHAs) } \\
\text { with population health mandates (Church and Smith, 2008; Mitton, Patten and } \\
\text { Donaldson et al., 2004) may also make it easier for these decision makers to exercise } \\
\text { autonomy in search of high performance PSRA. } \\
\text { Comments from our case studies are consistent with these suggestions. }\end{array}$ \\
\hline $\begin{array}{l}\text { S2: Mechanisms are } \\
\text { established for } \\
\text { engagement of staff } \\
\text { (clinical and non- } \\
\text { clinical) in PSRA } \\
\text { decisions, with } \\
\text { particular though not } \\
\text { exclusive attention to } \\
\text { physicians. May } \\
\text { include the use of } \\
\text { incentives to } \\
\text { encourage } \\
\text { participation. }\end{array}$ & $\begin{array}{l}\text { The idea of incentives is strongly rooted in economic theory, though they can be } \\
\text { controversial and have not been widely adopted. The main example of a structural } \\
\text { measure for seeking clinical and non-clinical staff participation in PSRA has been to } \\
\text { ensure that programs which offer ideas for service reduction are allowed to retain } \\
\text { some of the freed up money to reinvest in their own area (Haas et al., 2012; Jan, 2000; } \\
\text { Kapiriri and Martin, 2009). } \\
\text { None of our case study respondents reported employing this policy. }\end{array}$ \\
\hline $\begin{array}{l}\text { S3: There is a means to } \\
\text { coordinate priority } \\
\text { setting activity across } \\
\text { all organizational } \\
\text { planning processes } \\
\text { (e.g., strategic } \\
\text { planning, capital } \\
\text { projects, foundation } \\
\text { fundraising, etc.). }\end{array}$ & $\begin{array}{l}\text { In the Canadian context (and likely elsewhere) operational and capital spending are } \\
\text { decided separately. We posit this as a potential barrier, though perhaps it is so familiar } \\
\text { that it fails to register as a concern for managers in this study or others reported in the } \\
\text { literature. } \\
\text { Linking the activities of independent, voluntary fundraising groups more closely to } \\
\text { organization-wide priorities should also be expected to be challenging. }\end{array}$ \\
\hline $\begin{array}{l}\text { S4: There is relative } \\
\text { stability of } \\
\text { organizational } \\
\text { structure and } \\
\text { continuity of } \\
\text { personnel. }\end{array}$ & $\begin{array}{l}\text { Logic suggests that limited turnover may become undesirable if it serves only to } \\
\text { prevent acceptance of new ideas or to re-enforce members' joint commitment to a less- } \\
\text { than-optimal path. This does not appear to have been much addressed in the literature. }\end{array}$ \\
\hline $\begin{array}{l}\text { S5: Adequate but not } \\
\text { excessive time and } \\
\text { resources are } \\
\text { committed to PSRA. }\end{array}$ & $\begin{array}{l}\text { Too little time can also be devoted to this key management function. Rushed decision } \\
\text { making can lead to decisions that are not properly researched or debated (Hunter, } \\
\text { 1979). This side of the problem is rarely raised in the literature however, and was not } \\
\text { reported in any of our own cases. }\end{array}$ \\
\hline PROCESSES & PROCESSES \\
\hline $\begin{array}{l}\text { P1: PSRA at the } \\
\text { organization-wide } \\
\text { level is based on } \\
\text { economic and ethical } \\
\text { principles. It includes } \\
\text { well-defined, weighted } \\
\text { criteria which reflect } \\
\text { the organization's } \\
\text { values and strategic }\end{array}$ & $\begin{array}{l}\text { Having a review or appeals process is supposed to provide a means to correct } \\
\text { decisions that have been made in the absence of key facts or with an obvious } \\
\text { misinterpretation of information. This is emphasized by the Accountability for } \\
\text { Reasonableness (A4R) framework (Daniels and Sabin, 2002). The National Institute } \\
\text { for Clinical and Health Excellence (NICE) in the UK is one influential organization } \\
\text { which does provide for post-decision review (Littlejohns, Sharma, and Jeong, 2012). } \\
\text { However, few other studies report that healthcare organizations have such a system in } \\
\text { place; for instance, Menon, Stafinski and Martin (2007) find none in their survey of } \\
\text { Alberta's health authorities. None of our case study sites mentioned having an appeals }\end{array}$ \\
\hline
\end{tabular}




\begin{tabular}{|c|c|}
\hline $\begin{array}{l}\text { priorities; use of a } \\
\text { scoring tool to } \\
\text { operationalize criteria } \\
\text { in ranking individual } \\
\text { proposal; mechanisms } \\
\text { for incorporating best } \\
\text { available evidence; } \\
\text { and, a decision review } \\
\text { mechanism. }\end{array}$ & process. \\
\hline $\begin{array}{l}\text { P2: SMT ensures } \\
\text { effective } \\
\text { communication (both } \\
\text { internally and } \\
\text { externally) around its } \\
\text { priority setting and } \\
\text { resource allocation -- } \\
\text { leading to } \\
\text { transparency. }\end{array}$ & $\begin{array}{l}\text { While general recommendations to improve communication are common, it is less } \\
\text { clear exactly what information needs to be shared. We would suggest that } \\
\text { communication should occur with respect to the actual resource allocation decisions } \\
\text { which are made, the criteria used to make these decisions, the results of any appeals } \\
\text { process, and whether or not the decisions are implemented as planned. The greatest } \\
\text { challenge would appear to be with the final aspect of this list. Teng et al.'s study of } \\
\text { BC's PHSA ( } 2007) \text { found that decisions were said to be communicated, but not the } \\
\text { rationale for them. }\end{array}$ \\
\hline $\begin{array}{l}\text { P3: Skill development } \\
\text { for PSRA occurs } \\
\text { throughout the } \\
\text { organization including } \\
\text { managers, directors, } \\
\text { senior executive and } \\
\text { clinical leaders. }\end{array}$ & $\begin{array}{l}\text { We note that neither literature nor case studies appear to speak to how training and } \\
\text { education might differ for senior or middle managers. }\end{array}$ \\
\hline $\begin{array}{l}\text { P4: Follow through on } \\
\text { decisions -- SMT puts } \\
\text { in place appropriate } \\
\text { change management } \\
\text { strategies, with } \\
\text { performance } \\
\text { measurement, tracking } \\
\text { of outcomes, and } \\
\text { responds as needed. }\end{array}$ & $\begin{array}{l}\text { Front line staff can transform or even subvert policy intention via their discretionary } \\
\text { actions (Lipsky, 1980) - in this context most importantly meaning that intended } \\
\text { efficiency gains, cost savings or enhancements in social equity may not be achieved. } \\
\text { This insight from the larger management literature has not been the focus of explicit } \\
\text { PSRA research. }\end{array}$ \\
\hline $\begin{array}{l}\text { P5: A skilled internal } \\
\text { project coordinator has } \\
\text { responsibility for } \\
\text { overseeing the } \\
\text { organization-wide } \\
\text { PSRA effort. }\end{array}$ & $\begin{array}{l}\text { The exact nature of this role has remained undefined within the literature. Our findings } \\
\text { begin to articulate some of its specific grounds of importance. }\end{array}$ \\
\hline $\begin{array}{l}\text { ATTITUDES AND } \\
\text { BEHAVIOURS }\end{array}$ & ATTITUDES AND BEHAVIOURS \\
\hline $\begin{array}{l}\text { A1: Working } \\
\text { relationships within the } \\
\text { SMT are respectful and } \\
\text { characterized by } \\
\text { jointly addressing } \\
\text { challenges, mutual } \\
\text { trust, honesty, and the } \\
\text { open and frank } \\
\text { exchange of views. }\end{array}$ & $\begin{array}{l}\text { We speculate that most of our knowledge about the influence of good relationships } \\
\text { comes from organizations where such relationships exist - dysfunctional management } \\
\text { groups are unlikely to allow researchers to access their inner workings. }\end{array}$ \\
\hline $\begin{array}{l}\text { A2: There is a culture } \\
\text { of improvement. The } \\
\text { SMT strives for } \\
\text { excellence, and is }\end{array}$ & $\begin{array}{l}\text { While our cases and the PSRA literature stress the role of organizational culture, the } \\
\text { connection between culture and performance so far seems to be based on relatively } \\
\text { weak evidence (Scott et al., 2003). }\end{array}$ \\
\hline
\end{tabular}




\begin{tabular}{|c|c|}
\hline $\begin{array}{l}\text { willing to seek out and } \\
\text { learn from what peers } \\
\text { and leading } \\
\text { organizations are } \\
\text { doing. }\end{array}$ & \\
\hline $\begin{array}{l}\text { A3: Decisions are } \\
\text { made with a system- } \\
\text { wide perspective and a } \\
\text { view to their long-term } \\
\text { strategic alignment } \\
\text {--Senior leaders adopt } \\
\text { a system-wide point of } \\
\text { view while considering } \\
\text { how decisions will be } \\
\text { experienced across } \\
\text { Departments and over } \\
\text { a multi-year } \\
\text { timeframe. } \\
\text {--SMT is willing to } \\
\text { look beyond } \\
\text { incremental spend to } \\
\text { re-assess base budgets, } \\
\text { i.e., to pursue marginal } \\
\text { analysis and } \\
\text { disinvestment } \\
\text { opportunities }\end{array}$ & $\begin{array}{l}\text { Our case study data show that all of these six Canadian organizations still struggle } \\
\text { with how to fully integrate this aspect into PSRA practice. The wide literature on } \\
\text { disinvestment does not appear yet to have translated into widely known and applicable } \\
\text { practical approaches. }\end{array}$ \\
\hline $\begin{array}{l}\text { A4: Fit of priority } \\
\text { setting decisions with } \\
\text { social and community } \\
\text { values is sought. } \\
\text { Public participation } \\
\text { and input is valued; it } \\
\text { is integrated into } \\
\text { decisions in } \\
\text { meaningful ways; } \\
\text { consideration is given } \\
\text { to how decisions align } \\
\text { with external partners } \\
\text { and the larger health } \\
\text { system }\end{array}$ & $\begin{array}{l}\text { Priority setting literature has rarely explored if resource allocation within health } \\
\text { organizations is affected by an awareness of what others within the larger system are } \\
\text { doing. Some studies of the NHS are an exception. Hunter (1979) noted poor linkages } \\
\text { between health authorities and local governments; thirty years on, McCafferty et al. } \\
\text { (2012) describe partnering as a continued weakness of English Primary Care Trust } \\
\text { commissioning organizations in the re-organized NHS (see also Robinson et al., } \\
\text { 2012a). This lacuna is perhaps a key lapse as planning and delivery of public services } \\
\text { is increasingly happening through various network forms (Rhodes, 1997). }\end{array}$ \\
\hline $\begin{array}{l}\text { A5: SMT displays } \\
\text { strong leadership for } \\
\text { PSRA-SMT is aware } \\
\text { of and manages the } \\
\text { external environment } \\
\text { and other constraining } \\
\text { factors, and is willing } \\
\text { to take and stand } \\
\text { behind tough } \\
\text { decisions. }\end{array}$ & $\begin{array}{l}\text { There is very little in the literature about what qualities make for strong leadership in } \\
\text { respect of PSRA (Dickinson et al., 2011; one of the few exceptions is Reeleeder et al., } \\
\text { 2006). Dickinson et al. (2011) argue that effective leaders for PSRA must also have } \\
\text { personal and interpersonal skills that build alliances and facilitate long-term strategic } \\
\text { thinking. "Priority setting requires political acumen and skills in relationship } \\
\text { management and coalition building, so that 'tough choices' can be taken and } \\
\text { implemented" (Robinson et al, 2012b, p. 2392). } \\
\text { Respondents in our case study sites expressed strong support for their leadership } \\
\text { teams, but we were unable to obtain much specific information as to what } \\
\text { characteristics were linked to any ability to perform well in PSRA. }\end{array}$ \\
\hline OUTCOMES & OUTCOMES \\
\hline $\begin{array}{l}\text { O1: Actual reallocation } \\
\text { of financial resources } \\
\text { is achieved }\end{array}$ & Despite its prominence in the literature, case study sites did not generate this theme. \\
\hline O2: The process has & The various stakeholders obviously have different degrees of influence on whether and \\
\hline
\end{tabular}




\begin{tabular}{|l|l|}
\hline $\begin{array}{l}\text { the understanding and } \\
\text { endorsement of key } \\
\text { internal and external } \\
\text { stakeholders (e.g., } \\
\begin{array}{l}\text { Board of Directors, } \\
\text { staff and medical } \\
\text { leadership, Ministry, } \\
\text { public). }\end{array}\end{array}$ & $\begin{array}{l}\text { how formal PSRA proceeds. More research is probably required as neither our } \\
\text { empirical findings nor the literature tease out the impact which variations across these } \\
\text { stakeholders might have. } \\
\text { We speculate that this concept could include Sibbald et al's (2009) idea of 'positive } \\
\text { externalities' such as public debate and social learning, though this was not raised by } \\
\text { our respondents. }\end{array}$ \\
\hline $\begin{array}{l}\text { O3: There is greater } \\
\text { understanding among } \\
\text { participants of the } \\
\text { organization as a } \\
\text { whole, and of PSRA } \\
\text { practice. }\end{array}$ & $\begin{array}{l}\text { The learning benefits and changes in knowledge resulting from one's participation in a } \\
\text { management process has been extensively described in the evaluation literature as } \\
\text { 'process use' (Patton, 1998). This kind of change was reported as success in a southern } \\
\text { Alberta case (Halma et al., 2004). }\end{array}$ \\
\hline $\begin{array}{l}\text { O4: Resource } \\
\text { allocation decisions are } \\
\text { justified in light of the } \\
\text { organization's core } \\
\text { values. Progress is } \\
\text { made toward strategic } \\
\text { objectives. Improved } \\
\text { health (broadly } \\
\text { defined) is achieved as } \\
\text { a result of decisions } \\
\text { made through the RA } \\
\text { process. High quality } \\
\text { care is delivered. }\end{array}$ & $\begin{array}{l}\text { There has been almost no effort made by researchers to actually assess the link } \\
\text { PBMA could be evaluated through "addressing whether [it] leads to improved } \\
\text { population health" but that "such evaluations remain to be done" (p. 122-23). Despite } \\
\text { a decade having passed since these comments were made, the challenge has not been } \\
\text { taken up, at least to our knowledge. }\end{array}$ \\
\hline
\end{tabular}

\section{References}

Church, J. and N. Smith. 2008. Health care in Alberta: the introduction of health regions. Canadian Public Administration 51(2):217-238.

Daniels, N. and J. Sabin. Setting limits fairly: can we learn to share medical resources? 2002. Oxford: Oxford University Press.

Dickinson, H., T. Freeman, S. Robinson, and I. Williams. 2011. Resource scarcity and prioritysetting: from management to leadership in the rationing of health care? Public Money \& Management 5:363-370.

Haas, M., J. Hall, R. Viney, and G. Gallego. 2012. Breaking up is hard to do: why disinvestment in medical technology is harder than investment. Australian Health Review 36:148-152.

Halma, L., C. Mitton, C. Donaldson, and B. West. 2004. Case study on priority setting in rural southern Alberta: keeping the house from blowing in. Canadian Journal of Rural Medicine 9(1):26-36.

Hunter, D. 1979. Coping with uncertainty: decisions and resources within health authorities. Sociology of Health and Illness 1(1):40-68. 
Jan, S. 2000. Institutional considerations in priority setting: transactions cost perspective on PBMA. Health Economics 9(7):631-41.

Kapiriri, L. and D.K. Martin. 2009. Successful priority setting in low and middle income countries: A framework for evaluation. Health Care Analysis 18:129-147.

Lipsky, M. 1980. Street-level Bureaucracy. New York: Russell Sage.

Littlejohns, P., T. Sharma, and K. Jeong, K. 2012. Social values and health priority setting in England: 'values' based decision making. Journal of Health Organization and Management 26(3):363-371.

McCafferty, S., I. Williams, D. Hunter, S. Robinson, C. Donaldson, and A. Bate. 2012. Implementing world class commissioning competencies. Journal of Health Services Research and Policy 17(Suppl 1):40-48.

Menon, D., T. Stafinski, and D.K. Martin. 2007. Priority-setting for healthcare: who, how, and is it fair? Health Policy 84(2-3):220-233.

Mitton, C., and C. Donaldson. 2004. Health care priority setting: principles, practice and challenges. Cost Effectiveness and Resource Allocation 2(3). http://www.resourceallocation.com/content $/ 2 / 1 / 3$

Mitton, C., S. Patten, and C. Donaldson. 2004. Listening to the decision makers: refinement of macro-level PBMA in Alberta. Applied Health Economics and Health Policy 3(3):143-151.

Patton, M. Q. Utilization-focused evaluation: the new century text. (3rd ed.) 1997. Thousand Oaks, CA: Sage.

Reeleder, D., V. Goel, P.A. Singer, and D.K. Martin. 2006. Leadership and priority-setting: the perspective of hospital CEOs. Health Policy 79:24-34.

Rhodes, R.A.W. 1997. Understanding governance: policy networks, governance, reflexivity and accountability. Open University Press.

Robinson, S., H. Dickinson, T. Freeman, B. Rumbold, and I. Williams. 2012a. Structures and processes for priority-setting by health-care funders: a national survey of primary care trusts in England. Health Services Management Research 25:113-130.

Robinson, S., I. Williams, H. Dickinson, T. Freeman, and B. Rumbold, B. 2012b. Prioritysetting and rationing in health care: evidence from the English experience. Social Science and Medicine 75(12), 2386-2393.

Scott, T., R. Mannion, M. Marshall, and H. Davies. 2003. Does organisational culture influence health care performance? A review of the evidence. Journal of Health Services Research and Policy 8(2):105-117. 
Sibbald, S.L., P.A. Singer, R. Upshur, and D.K. Martin. 2009. Priority setting: what constitutes success? A conceptual framework for successful priority setting. BMC Health Services Research 9(43). doi:10.1186/1472-6963-9-43

Teng, F., C. Mitton, and J. MacKenzie. 2007. Priority setting in the provincial health services authority: survey of key decision makers. BMC Health Services Research 7(84). doi: 10.1186/1472-6963-7-84. 